\title{
PERAMALAN INFLOW UANG KARTAL BANK INDONESIA KPW TASIKMALAYA JAWA BARAT DENGAN METODE KLASIK DAN MODERN
}

\author{
Nur Silviyah Rahmi ${ }^{1}$ \\ ${ }^{1}$ Jurusan Statistika, Fakultas Matematika dan Ilmu Pengetahuan Alam, \\ Universitas Brawijaya Malang \\ Email : silviyahrahmi@ub.ac.id
}

\begin{abstract}
ABSTRAK
Ketersediaan uang kartal di Bank Indonesia (BI) dapat ditinjau melalui arus keluar masuknya uang kartal yang disebut dengan istilah inflow. Banyaknya uang yang beredar di masyarakat akan berpengaruh pada kondisi perekonomian suatu negara, sehingga Bank Indonesia (BI) menyusun perencanaan kebutuhan uang rupiah. Penelitian ini bertujuan untuk meramalkan inflow uang kartal di KPw Bank Indonesia (BI) Tasikmalaya dengan menggunakan pemodelan ARIMA, ARIMAX, Metode Dekomposisi, Metode Winter's, MLP (Multilayer Perceptron) atau FFNN (Feed Forward Neural Network), Regresi Time Series, Metode Nä̈ve dan Model Hybrid. Dari delapan metode runtun waktu tersebut baik klasik maupun modern akan dicari metode mana yang memberikan hasil akurasi ramalan yang terbaik dengan kriteria RMSE, MAPE dan MAD. Kesimpulan yang dihasilkan yaitu Hybrid ARIMA-NN yang merupakan gabungan dari model ARIMA dengan neural network tidak menjamin kinerja hasil peramalan yang lebih baik. Seperti yang disebutkan dalam hasil M3 Competition, semakin kompleks metode yang digunakan belum tentu metode tersebut menghasilkan akurasi yang lebih baik dibandingkan metode sederhana (klasik). Pada ramalan data inflow KPw BI Tasikmalaya Jawa Barat ini, menghasilkan kesimpulan bahwa metode regresi time series memiliki nilai kriteria pemodelan paling kecil dibandingkan dengan metode lainnya.
\end{abstract}

Kata kunci : Hybrid ARIMA-NN, Regresi Time Series, Inflow, Bank Indonesia.

\section{PENDAHULUAN}

Bank Indonesia adalah lembaga negara independen dan merupakan bank sentral Republik Indonesia yang mempunyai satu tujuan tunggal, yaitu mencapai dan memelihara kestabilan nilai rupiah. Dalam melaksanakan tugasnya, Bank Indonesia menyusun perencanaan kebutuhan uang (RKU). Uang kartal merupakan salah satu alat pembayaran tunai yang memiliki fungsi penting dalam mendukung transaksi perekonomian. Hal ini dikarenakan hampir semua kegiatan ekonomi, baik produksi, konsumsi serta investasi selalu melibatkan uang. Uang kartal yang diedarkan oleh Bank Indonesia ini digunakan sebagai alat pembayaran yang sah di wilayah Republik Indonesia.

Peredaran uang kartal baik di masyarakat maupun perbankan diatur oleh Bank Indonesia. Ketersediaan Uang Layak Edar (ULE) dapat ditinjau melalui arus keluar masuknya uang kartal di Bank Indonesia [1]. Aliran uang yang keluar dari Bank Indonesia kepada perbankan dan masyarakat disebut sebagai outflow sedangkan aliran uang yang masuk dari perbankan dan masyarakat kepada Bank Indonesia disebut sebagai inflow. Pola perkembangan Uang Layak Edar (ULE) tidak terlepas dari perkembangan aktivitas perekonomian Nasional dan pola musiman, dimana kenaikan ULE 
terjadi pada periode menjelang hari raya keagamaan, libur dan pendaftaran sekolah serta tahun baru.

Beberapa metode peramalan digunakan untuk memodelkan data time series. Namun penggunaan metode peramalan tersebut harus disesuaikan dengan kondisi atau pola data sehingga dapat diperoleh model yang terbaik [2]. Pada penelitian ini bertujuan untuk meramalkan inflow uang kartal di $\mathrm{KPw}$ Bank Indonesia (BI) Tasikmalaya dengan menggunakan pemodelan ARIMA, ARIMAX, Metode Dekomposisi, Metode Winter's, MLP (Multilayer Perceptron) atau FFNN (Feed Forward Neural Network), Regresi Time Series, Metode Naïve dan Model Hybrid. Dari delapan metode runtun waktu tersebut baik klasik maupun modern akan dicari metode mana yang memberikan hasil akurasi ramalan yang terbaik dengan kriteria RMSE, MAPE dan MAD.

Sampai saat ini, pihak Bank Indonesia belum mempunyai metode yang standar untuk memprediksi nilai inflow uang kartal di suatu KPw [3]. Dengan demikian, hasil dari penelitian ini diharapkan dapat menjadi salah satu kebijakan atau masukan yang utama bagi pihak Bank Indonesia dalam melakukan peramalan inflow uang kartal di suatu $\mathrm{KPw}$. Berdasarkan informasi terkait peramalan inflow uang kartal tersebut juga diharapkan dapat membantu pihak BI dalam melakukan kebijakan pengelolaan uang rupiah yang meliputi perencanaan, pencetakan, pengeluaran, pengedaran,penarikan, serta pemusnahan uang rupiah.

\section{ARIMA dan ARIMAX Model}

Model ARIMA musiman memiliki orde $\mathrm{p}$ sebagai operator dari AR, orde $\mathrm{d}$ merupakan differencing,orde q sebagai operator dari MA. Pada model ARIMA $(\mathrm{p}, \mathrm{d}, \mathrm{q})$, nilai yang akan datang dari suatu variabel diasumsikan sebagai fungsi linier dari beberapa pengamatan di masa lalu dan random error. Model ARIMA $(\mathrm{p}, \mathrm{d}, \mathrm{q})$ secara umum, yaitu

$\phi_{p}(B)(1-B)^{d} Z_{t}=\theta_{0}+\theta_{q}(B) a_{t}$

dengan

$\phi_{p}(B)=\left(1-\phi_{1} B-\cdots-\phi_{p} B^{p}\right), \theta_{q}(B)=$ $\left(1-\theta_{1} B-\cdots-\theta_{q} B^{q}\right)$

adalah intercept pada model untuk difference ke-d. Pembuatan model ARIMA dapat dilakukan dengan menggunakan tiga prosedur yaitu identifikasi model, estimasi model dan cek diagnosa. Identifikasi model merupakan metodologi untuk mengidentifikasi perlunya suatu transformasi seperti transformasi untuk stasioner dalam varians, transformasi differencing, keputusan untuk memasukkan parameter $\theta_{0}$ ketika $\mathrm{d}>0$ dan penentuan order $\mathrm{p}$ dan $\mathrm{q}$ pada ARIMA. Estimasi parameter yang digunakan dalam penelitian ini menggunakan conditional least square kemudian dilanjutkan uji statistik untuk menentukan apakah parameter tersebut signifikan atau tidak.

Pemodelan time series dengan menambahkan beberapa variabel yang dianggap memiliki pengaruh yang signifikan terhadap data seringkali dilakukan untuk menambah akurasi peramalan yang dilakukan dalam suatu penelitian [4]. Model ARIMAX adalah modifikasi dari model dasar ARIMA seasonal dengan penambahan variabel prediktor. Efek kalender variasi merupakan salah satu variabel prediktor yang seringkali digunakan dalam pemodelan tersebut. Secara umum, jika Yt adalah suatu time series dengan efek kalender variasi, maka model ARIMAX ditulis sebagai berikut:

$$
\begin{aligned}
& Y_{t}=\beta_{1} V_{1, t}+\beta_{2} V_{2, t}+\cdots+\beta_{p} V_{p, t}+ \\
& \frac{\theta_{q}(B) \Theta Q\left(B^{S}\right)}{\emptyset_{p}(B) \Phi P\left(B^{S}\right)(1-B)^{d}\left(1-B^{S}\right)^{D}} a_{t}
\end{aligned}
$$

Pemodelan di atas terdiri dari variabel respon, yaitu data time series dan kalender variasi yang berperan sebagai dummy variable. Menurut Lee \& Suhartono langkah penyelesaian analisis 
dengan menggunakan model ARIMAX adalah sebagai berikut:

1. Penentuan variabel dummy berdasarkan periode kalender variasi

2. Melakukan pemodelan regresi dengan persamaan:

$Y_{t}=\beta_{1} V_{1, t}+\beta_{2} V_{2, t}+\cdots+\beta_{p} V_{p, t}+w_{t}$

3. Memodelkan residual hasil analisis regresi dengan menggunakan model ARIMA

4. Melakukan pemodelan keseluruhan untuk ARIMAX

5. Melakukan pengecekan signifikansi parameter dan tes diagnosa sehingga proses stasioner dan error dari model mencapai kondisi white noise.

\section{Metode Dekomposisi dan Metode Winter's}

Dekomposisi adalah suatu pendekatan analisis data runtun waktu untuk mengidentifikasi faktor-faktor komponen yang mempengaruhi masing-masing nilai dari data. Setiap komponen diidentifikasi secara terpisah. Proyeksi dari masingmasing komponen kemudian dapat dikombinasikan untuk menghasilkan ramalan nilai masa depan dari data runtun waktu [5]. Beberapa dekomposisi yang telah dikembangkan dan digunakan:

1. Dekomposisi Aditif

Dekomposisi Aditif mendekomposisi data runtun waktu pada komponenkomponen tren, musiman, siklus dan galat (error). Metode ini mengidentifikasi ramalan masa depan dan menjumlahkan proyeksi hasil peramalan. Model diasumsikan bersifat aditif (semua komponen ditambahkan untuk mendapatkan hasil peramalan). Persamaan model ini adalah:

$X_{t}=T_{t}+C_{t}+S_{t}+I_{t}$

$\mathrm{X}_{\mathrm{t}}$ adalah data runtun waktu, $\mathrm{T}_{\mathrm{t}}$ adalah komponen tren (trend), $\mathrm{C}_{\mathrm{t}}$ adalah komponen siklus (cycle), $\mathrm{S}_{\mathrm{t}}$ adalah komponen musiman (seasonal), dan $\mathrm{I}_{\mathrm{t}}$ adalah komponen tak beraturan [6].
2. Dekomposisi Multiplikatif

Dekomposisi multiplikatif yaitu mendekomposisi data runtun waktu pada komponen-komponen tren, musiman, siklus dan galat kemudian memprediksi nilai masa depan. Model diasumsikan bersifat multiplikatif (semua komponen dikalikan satu sama lain untuk mendapatkan model peramalan).

Metode pemulusan eksponensial linear dari Winter's digunakan untuk peramalan jika data memiliki komponen musiman. Metode Winter's didasarkan pada tiga persamaan pemulusan, yakni persamaan pemulusan keseluruhan, pemulusan trend, dan persamaan pemulusan musiman. Ketiga persamaan dari Winter's exponential smoothing adalah sebagai berikut.

$S_{t}=a\left(X_{t}-I_{m t-L}\right)+(1-\alpha)\left(S_{t-1}+b_{t-1}\right)(4)$

Metode Winter's membutuhkan tiga parameter pemulusan (alfa, beta, dan gamma) yang dapat bernilai antara 0 dan 1 , sehingga banyak kombinasi yang harus dicobakan sebelum nilai ketiga parameter yang optimal ditentukan. Metode alternatif yang dapat mengurangi keraguan tentang nilai optimal adalah mencari nilai taksiran awal yang lebih baik, lalu menetapkan nilai yang kecil untuk ketiga parameter pemulusan yaitu (sekitar 0,1 sampai dengan 0,3). Nilai 0,1 membuat ramalan bersifat terlalu berhatihati, sedangkan nilai 0,3 memberikan sistem yang lebih responsif.

\section{MLP (Multilayer Perceptron) atau FFNN (Feed Forward Neural Network) dan Regresi Time Series}

Artificial Neural networks atau neural network merupakan sistem pengolahan informasi yang memiliki karakteristik serupa dengan jaringan syaraf manusia. Ada 3 jenis komponen biologis yang membangun jaringan syaraf tiruan, yaitu dendrit, soma dan akson. Arsitektur yang digunakan dalam penelitian ini adalah 
Multi Layer Perceptron (MLP). Multi Layer Feed Forward Neural networks (FFNN) atau Multi Layer Perceptron (MLP) adalah perceptron dengan tambahan satu atau lebih lapisan tersembunyi diletakkan antara input dan output network. Nilai output MLP $\left(Z_{t}\right)$ dengan satu hidden layer dihitung melalui persamaan di bawah ini.

$\hat{Z}_{t}=\varphi_{k}\left(b_{k}+\right.$

$\left.\sum_{j \rightarrow k} w_{k j} a_{j}\left(b_{j}+\sum_{i \rightarrow j} w_{j i} z_{t-i}\right)\right)$

Regresi dalam konteks time series memiliki bentuk yang sama dengan regresi linier umum [7]. Dengan mengasumsikan output atau bentuk dependen $\mathrm{y}_{\mathrm{t}}$, untuk $\mathrm{t}=1,2, \ldots, \mathrm{n}$, yang dipengaruhi oleh kemungkinan data input atau independen, dimana inputnya merupakan fix dan diketahui, hubungan ini dapat ditunjukkan dengan model regresi linier [8]. Jika data $\mathrm{y}_{\mathrm{t}}$ memiliki trend, trend $(\mathrm{t})$ digunakan sebagai input, yang dapat ditulis sebagai berikut:

$y_{t}=\beta_{0}+\beta_{1} S_{1, t}+\beta_{2} S_{2, t}+\cdots+\beta_{s} S_{s, t}+a_{t}(6)$

dimana $w_{t}$ merupakan residual, yang mengalami proses independen dan identik serta berdistribusi normal dengan nilai mean 0 dan varian $\sigma_{w}^{2}$. Bentuk data seasonal $\mathrm{S}_{1, \mathrm{t}}, \mathrm{S}_{2, \mathrm{t}}, \ldots, \mathrm{S}_{\mathrm{s}, \mathrm{t}}$ merupakan variabel dummy untuk bentuk seasonal. Sebagai contoh jika datanya bulanan, maka ada 12 variabel dummy seasonal, 1 dummy untuk 1 bulan. Jika data kuarter, maka ada 3 variabel dummy, 1 dummy untuk kuarter pertama dan seterusnya.

\section{Metode Naïve dan Model Hybrid}

Model naïve adalah metode paling sederhana dalam peramalan. Dalam data time series, dengan menggunakan pendekatan naïve akan menghasilkan perkiraan yang sama dengan nilai terakhir yang diobservasi [9]. Jika deret waktu diyakini memiliki musiman, pendekatan naïve musiman mungkin lebih tepat dimana perkiraannya sama dengan nilai dari musim lalu. Metode naïve juga bisa menggunakan drift, yang akan mengambil pengamatan terakhir ditambah perubahan rata-rata dari pengamatan pertama sampai pengamatan terakhir. Model naïve untuk setiap kondisi disajikan sebagai berikut:

Untuk stationary data :

$\widehat{Y}_{t+1}=Y_{t}$

Untuk trend data :

$\hat{Y}_{t+1}=Y_{t}+\left(Y_{t}-Y_{t-1}\right)$

Untuk seasonal data:

$\widehat{\boldsymbol{Y}}_{\boldsymbol{t}+\mathbf{1}}=\boldsymbol{Y}_{(\boldsymbol{t}+\mathbf{1})-s}$

Hybrid adalah kombinasi dua atau lebih sistem dalam satu fungsi, dalam hal ini adalah kombinasi antara ARIMA dengan Neural Network. Banyak peneliti menggunakan metode hybrid karena diharapkan dapat saling melengkapi karena dalam dunia nyata jarang ditemukan kejadian time series yang murni linier ataupun murni non-linier [10]. Secara umum kombinasi dari model time series yang linier dan non-linier dapat dituliskan sebagai berikut :

$y_{t}=L_{t}+E_{t}$

dimana $L_{t}$ menunjukkan komponen linier dan $E_{t}$ menunjukkan komponen non linier. Terdapat dua komponen yang harus diestimasi dari data, yaitu misalkan model ARIMA digunakan untuk menyelesaikan kasus yang linier, dimana residual dari model yang linier masih mengandung informasi hubungan nonlinier. Dapat dituliskan :

$e_{t}=y_{t}-\hat{L}_{t}$

dimana $\hat{L}_{t}$ nilai ramalan ARIMA pada waktu t. Persamaan dari residual untuk model NN dapat dituliskan sebagai berikut:

$e_{t}=f\left(e_{t-1} \cdot e_{t-2} \ldots e_{t-n}\right)+\varepsilon_{t}$ dimana $f$ adalah fungsi non linier yang dijelaskan oleh $\mathrm{NN}$ dan $\varepsilon_{\mathrm{t}}$ adalah error yang acak, sehingga fungsi kombinasi untuk memprediksi adalah $\hat{y}_{t}=\hat{L}_{t}+\hat{E}_{t}$.

\section{Pemilihan Model Terbaik}

Pemilihan model terbaik dilakukan jika terdapat lebih dari satu model yang 
layak dipakai. Pada pendekatan outsample, model terbaik akan dipilih berdasarkan nilai kesalahan peramalan yang paling kecil [11]. Kriteria yang digunakan dalam penelitian ini adalah RMSE, MAPE dan MAD yang dirumuskan sebagai berikut.

RMSE (Root Mean Square Error):

$R M S E=\sqrt{\frac{\sum\left(Y_{t}-Y_{t+1}\right)^{2}}{n}}$

MAPE (Mean Absolute Percentage Error), mengukur ketepatan nilai dugaan model, yang dinyatakan dalam bentuk rata-rata persentase absolut kesalahan:

$M A P E=\frac{\sum\left|\left(y_{t}-\hat{y}_{t}\right) / y_{t}\right|}{n} \times 100$

MAD (Mean Absolute Deviation), mengukur ketepatan nilai dugaan model,yang dinyatakan dalam bentuk rata-rata absolut kesalahan:

$M A D=\frac{\sum\left|\left(y_{t}-\hat{y}_{t}\right)\right|}{n}$

\section{METODELOGI PENELITIAN}

Data yang digunakan adalah data sekunder yang terdiri dari data inflow uang kartal di KPw Bank Indonesia (BI) Tasikmalaya Jawa Barat. Periode data yang digunakan adalah data bulanan dari Januari 2003 hingga Desember 2014. Variabel yang digunakan adalah data inflow uang kartal BI KPw Tasikmalaya Jawa Barat. Langkah-langkah dalam peramalan inflow uang kartal di KPw BI Tasikmalaya Jawa Barat adalah dengan membagi data menjadi dua bagian yaitu periode Januari 2003-Februari 2013 dijadikan sebagai data in-sample sedangkan Maret 2014-Desember 2014 dijadikan sebagai data out-sample Data in sample digunakan untuk pembentukan model (training), sedangkan data out sample digunakan untuk pemilihan ramalan terbaik (testing).

Kemudian mengaplikasikan model ARIMA, ARIMAX, Metode Dekomposisi, Metode Winter's, MLP (Multilayer Perceptron) atau FFNN
(Feed Forward Neural Network), Regresi Time Series, Metode Naïve dan Model Hybrid pada data inflow uang kartal di KPw Bank Indonesia (BI) Tasikmalaya Jawa Barat. Langkah selanjutnya yaitu menghitung pemilihan model terbaik dengan pendekatan out-sample, model terbaik akan dipilih berdasarkan nilai kesalahan peramalan yang paling kecil. Kriteria yang digunakan adalah RMSE, MAPE dan MAD dan menarik kesimpulan.

\section{HASIL DAN PEMBAHASAN ARIMA dan ARIMAX Model}

Tahap yang pertama dalam analisis time series adalah mengindentifikasi time series plot yang digunakan untuk melihat inflow uang kartal di KPw Bank Indonesia (BI) Tasikmalaya Jawa Barat.

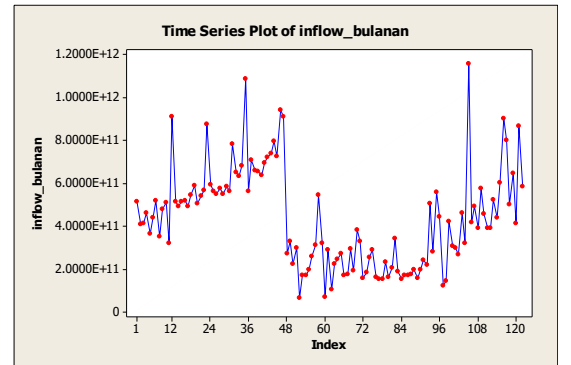

Gambar 1. Timeseries Plot Inflow KPw BI Tasikmalaya

Berdasarkan Gambar 1 terlihat bahwa data inflow uang kartal di $\mathrm{KPw}$ Bank Indonesia (BI) Tasikmalaya Jawa Barat belum stasioner. Data tidak stasioner dalam mean karena berpola trend naik dan menunjukkan pola ACF yang turun secara lambat, sehingga perlu dilakukan penanganan berupa differencing dan transformasi.

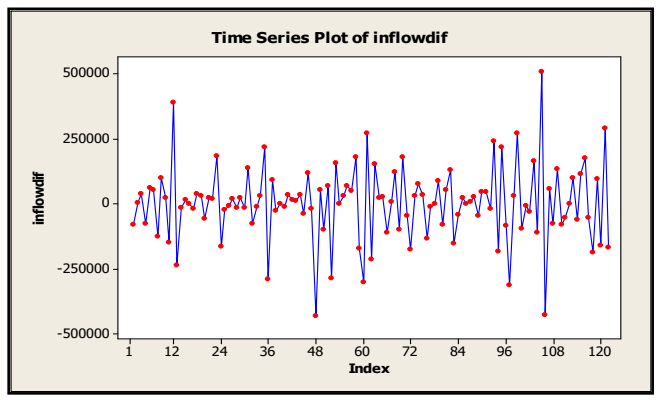

Gambar 2. Timeseries Plot Inflow Setelah Differencing dan Transformasi 
Berdasarkan plot ACF dan PACF pada Gambar 2 dapat dilihat bahwa pola musiman menghilang setelah differencing 1. Pola musiman yang terbentuk diawal sudah tidak terlihat lagi setelah dilakukan differencing 1 , sehingga model dugaan yang terbentuk setelah dilakukan differencing adalah ARIMA $(0,1,1)(0,1,1)^{12}$ dan ARIMA $(1,1,1)(1,1,1)^{12}$. Langkah selanjutnya setelah mengidentifikasi model ARIMA adalah mengestimasi parameter dan pengujian signifikansi parameter. Metode yang digunakan dalam estimasi parameter yaitu Conditionally Least Square $(C L S)$. Estimasi parameter pada masing-masing model ARIMA memberikan hasil pada tabel 1 .

Tabel 1. Estimasi dan Pengujian Signifikansi Parameter pada Model ARIMA

\begin{tabular}{cccc}
\hline $\begin{array}{c}\text { Model } \\
\text { Dugaan }\end{array}$ & Parameter & Estimasi & $\begin{array}{c}\text { P- } \\
\text { value }\end{array}$ \\
\hline ARIMA & MA1 & 0.6590 & $0.000^{*}$ \\
$(0,1,1)(0,1,1)^{12}$ & SMA12 & 0.8105 & $0.000^{*}$ \\
\hline & AR1 & -0.1078 & 0.458 \\
ARIMA & SAR12 & 0.1429 & 0.300 \\
$(1,1,1)(1,1,1)^{12}$ & MA1 & 0.6035 & $0.000^{*}$ \\
& SMA12 & 0.8192 & $0.000^{*}$ \\
\hline
\end{tabular}

Setelah mendapatkan model dugaan yang signifikan, selanjutnya dilakukan pemeriksaan terhadap residualnya. Asumsi residual yang harus terpenuhi pada model ARIMA yaitu white noise dan berdistribusi normal. Pemeriksaan asumsi white noise dengan menggunakan uji Ljung-Box dengan taraf signifikan $\alpha$ sebesar $5 \%$ dan $\mathrm{H}_{0}$ ditolak jika $\chi^{2}>$ $\chi_{(\alpha, K-p-q)}^{2}$. Hasil Uji Ljung-Box pada masing-masing model ARIMA menunjukkan bahwa semua model telah memenuhi asumsi white noise.

Selanjutnya dilakukan pengujian asumsi residual berdristribusi normal. Pengujian asumsi residual berdistribusi normal dengan uji Kolmogorov-Smirnov. Hasilnya menunjukkan bahwa model ARIMA $(0,1,1)(0,1,1)^{1}$ dan ARIMA $(1,1,1)(1,1,1)^{12}$ telah memenuhi asumsi distribusi normal. Selanjutnya pemilihan model terbaik dilakukan setelah didapatkan model yang signifikan dan memenuhi asumsi. Pemilihan model terbaik dilakukan dengan melihat kriteria out-sample. Hasilnya diringkas pada Tabel 2.

Tabel 3. Pemilihan Model Terbaik ARIMA dan

\begin{tabular}{lccc}
\multicolumn{1}{c}{ ARIMAX } & Nilai & \multicolumn{1}{c}{$\begin{array}{c}\text { Nilai } \\
\text { MAdel Dugaan }\end{array}$} & $\begin{array}{c}\text { Nilai } \\
\text { MAPE }\end{array}$ \\
\hline $\begin{array}{l}\text { ARIMA } \\
(0,1,1)(0,1,1)^{12}\end{array}$ & $\mathbf{1 6 4 6 4 1 . 6}$ & $\mathbf{1 3 7 8 8 2 . 1}$ & $\mathbf{1 7 . 9 6 0}$ \\
$\begin{array}{l}\text { ARIMA } \\
(1,1,1)(1,1,1)^{12}\end{array}$ & 166985.1 & 139105.1 & 18.354 \\
\hline $\begin{array}{l}\text { ARIMAX } \\
(0,1,12)\end{array}$ & 238276 & 165342 & 24.56 \\
$\begin{array}{l}\text { ARIMAX } \\
(0,1,1)\end{array}$ & $\mathbf{1 3 8 1 4 7}$ & $\mathbf{1 0 9 8 7 0}$ & $\mathbf{1 7 . 8 9}$ \\
\hline
\end{tabular}

Berdasarkan Tabel 4 diatas diperoleh model terbaik yaitu ARIMA $(0,1,1)(0,1,1)^{12}$ karena memiliki nilai kriteria out-sample terkecil. Model yang terbentuk yaitu sebagai berikut.

$\mathrm{Z}_{\mathrm{t}}=0.6590 \mathrm{Z}_{\mathrm{t}-1}+0.8105 \mathrm{Z}_{\mathrm{t}-2}+\mathrm{Z}_{\mathrm{t}-12}-$ $0.6590 \mathrm{Z}_{\mathrm{t}-13}-0.8105 \mathrm{Z}_{\mathrm{t}-14}+$ at -1.4695 at-12

Pemodelan time series dengan menambahkan beberapa variabel yang dianggap memiliki pengaruh yang signifikan terhadap data seringkali dilakukan untuk menambah akurasi peramalan. Model ARIMAX adalah modifikasi dari model dasar ARIMA seasonal dengan penambahan variabel prediktor. Efek kalender variasi merupakan salah satu variabel prediktor yang sering digunakan dalam pemodelan [12]. Secara umum, jika $Y_{t}$ adalah suatu time series dengan efek kalender variasi, maka model ARIMAX menunjukkan model terbaik yaitu Model ARIMAX $(0,1,1)$ dengan variabel dummy $C_{1 t} s / d$ $\mathrm{C}_{4 \mathrm{tm} 1}$ (Idul Fitri) karena memiliki nilai kriteria out-sample terkecil dengan nilai MAPE yaitu 17.89 , nilai RMSE yaitu 138147 dan nilai MAD yaitu 109870 .

\section{Metode Dekomposisi dan Metode Winter's}

Metode dekomposisi aditif diasumsikan bersifat aditif (semua komponen ditambahkan untuk 
mendapatkan hasil peramalan). Persamaan model ini adalah: $X_{t}=T_{t}+C_{t}+S_{t}+I_{t} \quad$ sedangkan dekomposisi multiplikatif diasumsikan bersifat multiplikatif (semua komponen dikalikan satu sama lain untuk mendapatkan model peramalan). Persamaan model ini adalah $X_{t}=T_{t} \times C_{t} \times S_{t} \times I_{t}$. Hasilnya diringkas pada Tabel 5 .

Tabel 6. Pemilihan Model Terbaik Metode

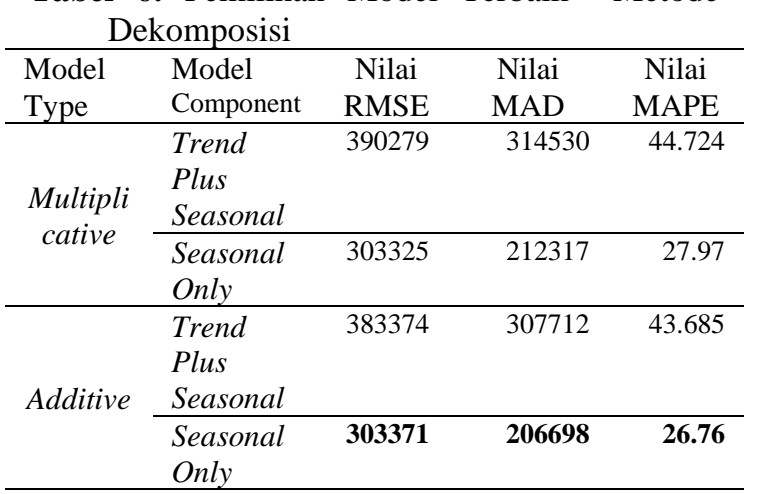

Berdasarkan Tabel 7 diatas diperoleh model terbaik yaitu Model Additive Seasonal Only karena memiliki nilai kriteria out-sample terkecil dengan nilai MAPE yaitu 26.76, nilai RMSE yaitu 303371 dan nilai MAD yaitu 206698.

Metode Winter's membutuhkan tiga parameter pemulusan (alfa, beta, dan gamma) yang dapat bernilai antara 0 dan 1 , sehingga banyak kombinasi yang harus dicobakan sebelum nilai ketiga parameter yang optimal ditentukan. Metode alternatif yang dapat mengurangi keraguan tentang nilai optimal adalah mencari nilai taksiran awal yang lebih baik, lalu menetapkan nilai yang kecil untuk ketiga parameter pemulusan yaitu (sekitar 0,1 sampai dengan 0,3). Nilai 0,1 membuat ramalan bersifat terlalu berhatihati, sedangkan nilai 0,3 memberikan system yang lebih responsif. Hasilnya diringkas pada Tabel 8. Berdasarkan Tabel 9 diatas diperoleh model terbaik yaitu Model Additive dengan alfa 0.1, gamma 0.2 dan delta 0.3 karena memiliki nilai kriteria out-sample terkecil dengan nilai MAPE yaitu 47.34, nilai RMSE yaitu 317356 dan nilai MAD yaitu 261791.

Tabel 10. Pemilihan Model Metode Winter's

\begin{tabular}{cccccr}
\hline Alfa & Gamma & Delta & $\begin{array}{c}\text { Nilai } \\
\text { RMSE }\end{array}$ & $\begin{array}{c}\text { Nilai } \\
\text { MAD }\end{array}$ & $\begin{array}{c}\text { Nilai } \\
\text { MAPE }\end{array}$ \\
\hline 0.1 & 0.1 & 0.1 & 403825 & 330218 & 59.836 \\
0.2 & 0.2 & 0.2 & 413424 & 330235 & 60.097 \\
0.3 & 0.3 & 0.3 & 844676 & 655915 & 123.904 \\
0.1 & 0.2 & 0.3 & 416421 & 326800 & 60.093 \\
\hline 0.1 & 0.1 & 0.1 & 346627 & 291968 & 53.093 \\
0.2 & 0.2 & 0.2 & 322298 & 269167 & 48.5133 \\
0.3 & 0.3 & 0.3 & 403406 & 337254 & 63.3611 \\
$\mathbf{0 . 1}$ & $\mathbf{0 . 2}$ & $\mathbf{0 . 3}$ & $\mathbf{3 1 7 3 5 6}$ & $\mathbf{2 6 1 7 9 1}$ & $\mathbf{4 7 . 3 4 0}$ \\
0.3 & 0.1 & 0.2 & 330614 & 276957 & 50.195 \\
0.2 & 0.3 & 0.1 & 320929 & 268634 & 48.007 \\
\hline
\end{tabular}

MLP (Multilayer Perceptron) atau FFNN (Feed Forward Neural Network) dan Regresi Time Series

Pemodelan MLP didahului dengan menentukan berat awal untuk pemodelan. Berat awal ditentukan secara acak. Fungsi pelatihan yang memperbaharui nilai bobot dan bias yang dikembangkan sesuai Optimal Levenberg. Simpul layer tersembunyi ditentukan oleh trial and error (1 sampai 10). Arsitektur yang digunakan adalah Multi Layer Perceptron dengan algoritma pelatihan Back propagation. Data inflow digunakan sebagai output dan dummy yang bersumber dari variasi kalender sebagai masukan dalam analisis ini. Arsitektur terbaik akan dipilih dengan RMSE terkecil. Hasil RMSE di setiap lapisan tersembunyi dengan pengujian 12 disajikan pada Tabel 11.

Tabel 12. Pemilihan Model MLP (Multilayer Perceptron) dan Regresi Time Series

\begin{tabular}{lcrr}
\hline MODEL & $\begin{array}{c}\text { Nilai } \\
\text { RMSE }\end{array}$ & \multicolumn{1}{c}{$\begin{array}{c}\text { Nilai } \\
\text { MAD }\end{array}$} & \multicolumn{1}{c}{$\begin{array}{c}\text { Nilai } \\
\text { MAPE }\end{array}$} \\
\hline Hidden 1 & 235665 & 175549 & 27.15 \\
Hidden 4 & 295378 & 199753 & 25.83 \\
Hidden 6 & $\mathbf{2 6 8 2 8 1}$ & $\mathbf{1 6 7 4 3 3}$ & $\mathbf{2 0 . 9 3}$ \\
\hline Lag1 & $\mathbf{1 2 9 5 5 2}$ & $\mathbf{8 3 6 7 1 . 8}$ & $\mathbf{1 0 . 4 1 7 0}$ \\
Lag2 & 289641 & 186613.0 & 24.8509 \\
Lag3 & 276929 & 177611.0 & 22.9769 \\
\hline
\end{tabular}

Berdasarkan Tabel 13 diatas diperoleh model terbaik yaitu Model Hidden 6 karena memiliki nilai kriteria out-sample terkecil dengan nilai MAPE yaitu 20.93, 
nilai RMSE yaitu 268281 dan nilai MAD yaitu 167433. Regresi dalam konteks time series memiliki bentuk yang sama dengan regresi linier umum. Dengan mengasumsikan output atau bentuk dependen $\mathrm{y}_{\mathrm{t}}$, untuk $\mathrm{t}=1,2, \ldots, \mathrm{n}$, yang dipengaruhi oleh kemungkinan data input atau independen, dimana inputnya merupakan nilai yang fix dan diketahui. Model terbaik yaitu regresi time series lag1 karena memiliki nilai kriteria outsample terkecil dengan nilai MAPE yaitu 10.417, nilai RMSE yaitu 129552 dan nilai MAD yaitu 83671.8.

\section{Metode Naïve dan Model Hybrid}

Model naïve adalah metode paling sederhana dalam peramalan. Dalam data time series, dengan menggunakan pendekatan naïve akan menghasilkan perkiraan yang sama dengan nilai terakhir yang diobservasi. Jika deret waktu diyakini memiliki musiman, pendekatan naïve musiman mungkin lebih tepat dimana perkiraannya sama dengan nilai dari musim lalu. Hasilnya diringkas pada Tabel 14.

Tabel 15. Pemilihan Model Metode Naïve

\begin{tabular}{lccc}
\hline \multicolumn{1}{c}{ Model } & $\begin{array}{c}\text { Nilai } \\
\text { RMSE }\end{array}$ & $\begin{array}{c}\text { Nilai } \\
\text { MAD }\end{array}$ & $\begin{array}{c}\text { Nilai } \\
\text { MAPE }\end{array}$ \\
\hline Stasioner & 344929 & 221226.5 & 32.407 \\
Trend & 607549 & 420007.3 & 66.939 \\
Seasonal & $\mathbf{1 5 9 7 2 7}$ & $\mathbf{1 3 5 3 0 4 . 3}$ & $\mathbf{2 1 . 7 6 0}$ \\
\hline $\begin{array}{l}\text { Hidden 4 } \\
\text { (Lag2) }\end{array}$ & 238155 & 167168 & 24.06 \\
$\begin{array}{l}\text { Hidden 5 } \\
\text { (Lag12) }\end{array}$ & $\mathbf{2 1 5 8 6 2}$ & $\mathbf{1 5 9 5 5 3}$ & $\mathbf{2 2 . 5 1}$ \\
\hline
\end{tabular}

Tabel 16 diatas diperoleh model terbaik yaitu model naïve seasonal karena memiliki nilai kriteria out-sample terkecil dengan nilai MAPE yaitu 21.760, nilai RMSE yaitu 159727 dan nilai MAD yaitu 135304.3. Berdasarkan analisis ARIMA diperoleh model terbaik yang digunakan dalam peramalan inflow uang kartal BI KPw Tasikmalaya Jawa Barat, yaitu model ARIMA $(0,1,1)(0,1,1)^{12}$ dapat dituliskan sebagai berikut :
$\mathrm{Z}_{\mathrm{t}}=0.6590 \mathrm{Z}_{\mathrm{t}-1}+0.8105 \mathrm{Z}_{\mathrm{t}-2}+\mathrm{Z}_{\mathrm{t}-12}-$ $0.6590 Z_{t-13}-0.8105 Z_{t-14}+a_{t}-1.4695$ at-12

Kemudian dilihat lag yang cut off pada plot PACF dari residual yang diperoleh dari model ARIMA $(0,1,1)(0,1,1)^{12}$. Berdasarkan plot PACF terlihat pada Gambar 4 bahwa lag cut off pada lag ke2 dan ke-12. Oleh karena itu digunakan lag 2 dan lag 12 sebagai input pada permodelan NN untuk meramalkan residual dari model. ARIMA $(0,1,1)(0,1,1)^{12}$.

Peramalan residual model ARIMA $(0,1,1)(0,1,1)^{12}$ dengan menggunakan NN dilakukan dengan input lag 2 yang berarti terdapat 1 buah neuron pada unit masukan dan jumlah unit pada hidden layer sebanyak 4 neuron berdasarkan hasil perhitungan pada Tabel 11. Serta input lag 12 yang berarti terdapat 1 buah neuron pada unit masukan dan jumlah unit pada hidden layer sebanyak 5 neuron. Sehingga diperoleh hasil peramalan dengan menggunakan hybrid ARIMA-NN untuk data inflow uang kartal BI KPw Tasikmalaya Jawa Barat menunjukkan model terbaik yaitu model hybrid ARIMA-NN lag12 karena memiliki nilai kriteria out-sample terkecil dengan nilai MAPE yaitu 22.51, nilai RMSE yaitu 215862 dan nilai MAD yaitu 159553.

\section{Perbandingan Metode Terbaik}

Berikut ini merupakan perbandingan delapan metode yang telah dicobakan, baik metode klasik maupun modern, metode Linear maupun non linear. Hasilnya diringkas pada Tabel 17. Berdasarkan Tabel 18 diatas diperoleh metode terbaik yaitu metode Regresi Time Series karena memiliki nilai kriteria out-sample terkecil dengan nilai MAPE yaitu 10.41, nilai RMSE yaitu 129552 dan nilai MAD yaitu 83671 . 
Tabel 19. Pemilihan Metode Time Series Terbaik

\begin{tabular}{|c|c|c|c|c|}
\hline METODE & MODEL & $\begin{array}{c}\text { Nilai } \\
\text { RMSE }\end{array}$ & $\begin{array}{l}\text { Nilai } \\
\text { MAD }\end{array}$ & $\begin{array}{c}\text { Nilai } \\
\text { MAPE }\end{array}$ \\
\hline ARIMA & $(0,1,1)(0,1,1)^{12}$ & 164641 & 137882 & 17.96 \\
\hline ARIMAX & $\begin{array}{l}(0,1,1) \text { (Idul } \\
\text { Fitri) }\end{array}$ & 138147 & 109870 & 17.89 \\
\hline Dekomposisi & $\begin{array}{l}\text { Additive } \\
\text { Seasonal Only }\end{array}$ & 303371 & 206698 & 26.76 \\
\hline Winter's & $\begin{array}{l}\text { Additive alfa } \\
0.1 \text {, gamma } \\
0.2 \text { dan delta } \\
0.3\end{array}$ & 317356 & 261791 & 47.34 \\
\hline $\begin{array}{l}\text { MLP } \\
\text { (Multilayer } \\
\text { Perceptron) }\end{array}$ & Hidden 6 & 268281 & 167433 & 20.93 \\
\hline $\begin{array}{l}\text { Regresi } \\
\text { Time Series }\end{array}$ & Lag1 & 129552 & 83671 & 10.41 \\
\hline $\begin{array}{l}\text { Metode } \\
\text { Naïve }\end{array}$ & Seasonal & 159727 & 135304 & 21.76 \\
\hline $\begin{array}{l}\text { Model } \\
\text { Hybrid }\end{array}$ & $\begin{array}{l}\text { Hidden } 5 \\
(\operatorname{Lag} 12)\end{array}$ & 215862 & 159553 & 22.51 \\
\hline
\end{tabular}

\section{KESIMPULAN}

Hybrid ARIMA-NN yang merupakan gabungan dari model ARIMA dengan neural network tidak menjamin kinerja hasil peramalan yang lebih baik. Seperti yang disebutkan dalam hasil M3 Competition, semakin kompleks metode yang digunakan belum tentu metode tersebut menghasilkan akurasi yang lebih baik dibandingkan metode sederhana (klasik).Pada ramalan data inflow $\mathrm{KPw}$ BI Tasikmalaya Jawa Barat ini, menghasilkan kesimpulan bahwa metode regresi time series memiliki nilai kriteria pemodelan paling kecil dibandingkan dengan metode lainnya.

\section{DAFTAR PUSTAKA}

[1] Bank Indonesia. (2017). Peraturan Bank Indonesia Nomor 14/7/PBI/2012 Tentang Pengelolaan Uang Rupiah. Diakses pada 20 Oktober 2015. Jakarta: Bank Indonesia.

[2] S. G. Makridakis, S. C. Wheelwright, and R. J. Hyndman. (1998), Forecasting: Methods and Applications, 3rd Edition, Wiley.

[3] Y. M. Hanim, Penerapan Regresi Time Series Dan Arimax Untuk
Peramalan Inflow Dan Outflow Uang Kartal Di Jawa Timur, DKI Jakarta Dan Nasional, Undergraduate, Institut Teknology Sepuluh Nopember, 2015.

[4] R. E. Wulansari and S. Suhartono. (2014). Peramalan Netflow Uang Kartal dengan Metode ARIMAX dan Radial Basis Function Network (Studi Kasus Di Bank Indonesia), Jurnal Sains dan Seni ITS, vol. 3, no. 2, Art. no. 2, doi: 10.12962/j23373520.v3i2.8064.

[5] Hanke and Wichern. (2009), Business Forecasting, 9th Edition, (accessed Oct. 08, 2020).

[6] G. E. P. Box, G. M. Jenkins, G. C. Reinsel, and G. M. Ljung. (2015). Time Series Analysis: Forecasting and Control, 5th Edition, Wiley.com.

[7] W. Wei. (2006). Time Series Analysis: Univariate and Multivariate Methods, 2nd edition

[8] R. Shumway and D. Stoffer. (2011). Time Series Analysis and Its Applications With R Examples, vol. 9.

[9] R. Hyndman, A. B. Koehler, J. K. Ord, and R. D. Snyder. (2008). Forecasting with Exponential Smoothing: The State Space Approach. Berlin Heidelberg: Springer-Verlag.

[10] G. P. Zhang. (2003), Time series forecasting using a hybrid ARIMA and neural network model, Neurocomputing, vol. 50, pp. 159175, doi: 10.1016/S09252312(01)00702-0.

[11] J. D. Cryer and K.-S. Chan. (2008). Time Series Analysis - With Applications in R, (accessed Oct. 08, 2020).

[12] M. Lee and Suhartono. (2010). Calendar variation model based on ARIMAX for forecasting sales data with Ramadhan effect, 2010. 